Acta Protozool. (2017) 56: 171-180

www.ejournals.eu/Acta-Protozoologica

doi:10.4467/16890027AP.17.015.7496

PROTOZOOLOGICA

\title{
Rumen Ciliate Biota of Domestic Cattle (Bos taurus taurus) in İstanbul, Turkey and Infraciliature of Metadinium medium (Entodiniomorphida, Ophryoscolecidae)
}

\author{
Gözde GÜRELLI, Fatma Tül Büşra AKMAN \\ Kastamonu University, Faculty of Sciences and Arts, Biology Department, Kastamonu, Turkey
}

\begin{abstract}
The species composition and distribution of ciliates were investigated in the rumen contents of 15 domestic cattle (Bos taurus taurus L.) living in the European part of İstanbul, Turkey. Thirty-five species and 13 morphotypes belonging to 13 genera were identified. The density of rumen ciliates in cattle was $31.8( \pm 21.3) \times 10^{4}$ cells ml $^{-1}$, and the mean number of ciliate species per host was $12.9 \pm 4.4$. Of the ciliate species, Dasytricha ruminantium, Entodinium simulans, and Isotricha prostoma were the most abundant, each with a prevalence of 93.3\%, whereas Diplodinium anisacanthum, D. dogieli, D. rangiferi, Enoploplastron triloricatum, Metadinium medium, and Ostracodinium munham were detected only in one animal (6.7\% prevalence). Eodinium posterovesiculatum m. bilobosum and $D$. dogieli are new host records for cattle in Turkey. The infraciliature of M. medium (Entodiniomorphida, Ophryoscolecidae) was examined and detected for the first time. The buccal infraciliature of M. medium was composed of three polybrachykineties, a kinety loop, and paralabial kineties. A large dorso-adoral polybrachykinety, a gentle S-shaped curved vestibular polybrachykinety, and a kinety loop between the dorso-adoral polybrachykinety and adoral polybrachykinety were characteristics. Because of these features, M. medium-type buccal infraciliature was between the Ostracodinium gracile-type buccal infraciliature and the Ostracodinium mammosum-type buccal infraciliature.
\end{abstract}

Key words: Cattle, ciliate, Entodiniomorphida, infraciliature, İstanbul, Metadinium medium, Ophryoscolecidae, rumen.

\section{INTRODUCTION}

All ruminants are dependent on the microorganisms that live in their rumen to breakdown ingested feed into a form that the host animal can utilize. Protozoa are part of this complex ruminal population and are essential for the nutritional well-being and productivity of the host ruminant (Williams and Coleman 1992).

Address for correspondence: Gözde Gürelli, Kastamonu University, Faculty of Sciences and Arts, Biology Department, 37150 Kuzeykent/Kastamonu, Turkey; E-mail: ggurelli@yahoo.com, ggurelli@kastamonu.edu.tr
The majority of these protozoa in the rumen are ciliates (Dehority 1986; Ogimoto and Imai 1981). These ciliates are endocommensal and are transmitted only by direct contact with the host during their lives, suggesting that the composition of rumen ciliate species has peculiarly evolved in narrow and limited areas (Imai 1988). Comparative studies of the ruminal ciliate populations of various hosts in different areas should provide the phylogenetic relationships between rumen ciliates and the host ruminant (Dehority 1978; Dogiel 1927; Gürelli 2014; Ito and Imai 1990) because the diversity of the present day ruminant ciliates is so overwhelming that it may be assumed that at least part of the diversity 
evolved recently parallel to the radiation of their present day hosts (Moon-van der Staay et al. 2014).

The city of İstanbul is a bridge between Europe and Asia, so it has geographical importance. No animal transportation is permitted between the Anatolian part and the European part of İstanbul to prevent transmission of some animal illnesses.

The aims of this study were to identify the ruminal ciliate biota in domestic cattle (Bos taurus taurus) living in the European part of İstanbul, Turkey, describe the infraciliature of Metadinium medium (Entodiniomorphida, Ophryoscolecidae), and discuss the evolution of rumen ciliates.

\section{MATERIALS AND METHODS}

Samples of ruminal contents were obtained from 15 domestic cattle (B. taurus taurus) held at slaughterhouses around the $\mathrm{Eu}-$ ropean part of İstanbul, Turkey from October 2014 to September 2015. Cattle were mostly fed on pasture before slaughter because they were outdoor-kept cattle. After slaughter, the rumen was cut open with a knife. A well-mixed ruminal digesta sample was immediately obtained by inserting a ladle into the open rumen and fixed with an equal volume of $18.5 \%$ formalin (Dehority 1984). An aliquot of each sample was stained with methyl green formalin saline (MFS) solution for total and differential cell counts (Ogimoto and Imai 1981). MFS was also used as a nuclear stain, and Lugol's iodine was used to visualize the skeletal plates (Gürelli 2016a).

Ciliate densities were calculated at $400 \times$ magnification with a Neubauer hemocytometer counting chamber. Differential counts of species were estimated from 50 to 800 cells on smear slides of each species (Gürelli 2016b).

The orientation of the ciliates for description was adopted from Dogiel (1927), in which the side closest to the macronucleus was called the dorsal side and the opposite side was called the ventral side.

The infraciliary bands were stained using the pyridinated silver carbonate impregnation method (Ito and Imai 1998). The term polybrachykinety was used for infraciliary bands composed of numerous, short, parallel kineties (Fernández-Galiano et al. 1985; Ito and Imai 1998, 2006).

Some samples were examined with a scanning electron microscope (SEM). MFS-fixed specimens were washed in distilled water overnight and post-fixed in a $2 \%(\mathrm{w} / \mathrm{v})$ osmium tetroxide aqueous solution for $4 \mathrm{~h}$ at room temperature. After five washes in distilled water, the specimens were dehydrated through an ethanol series (20 min in each concentration) and dried in a $\mathrm{CO}_{2}$ critical point dryer (Imai et al. 1992). The dried specimens were sputter-coated with gold and examined under a FEG 250 SEM (FEI-Quanta, Kastamonu, Turkey).

The classification and identification of the species were based on previously published species descriptions and taxonomic lists (Dehority 1993; Dogiel 1927; Ito and Imai 2003; Kofoid and MacLennan 1932; Lynn 2008; Ogimoto and Imai 1981).

\section{RESULTS}

The mean number $( \pm \mathrm{SD})$ of ciliates in the ruminal contents from 15 domestic cattle (B. taurus taurus) was $31.8( \pm 21.3) \times 10^{4}$ cells $\mathrm{ml}^{-1}$. Values ranged from 4.5 to $79.0 \times 10^{4}$ cells ml ${ }^{-1}$. Thirty-five species and 13 morphotypes belonging to 13 genera were detected. Of the ciliate species, Dasytricha ruminantium, Entodinium simulans, and Isotricha prostoma were the most abundant, each with a prevalence of $93.3 \%$, whereas Diplodinium anisacanthum, D. dogieli, D. rangiferi, Enoploplastron triloricatum, M. medium, and Ostracodinium munham were detected in only one animal (6.7\% prevalence) (Table 1). The total number of species per animal ranged from 5.0 to 19.0 , with a mean of $12.9 \pm 4.4$ (SD). In general, the ruminal ciliate fauna of cattle in İstanbul, Turkey was primarily composed of Entodinium species (mean: 61.8\%; range: 36.5-83.1\%). Eodinium posterovesiculatum $\mathrm{m}$. bilobosum and $D$. dogieli are new host records for cattle from Turkey.

\section{Infraciliature of Metadinium medium (Entodini- omorphida, Ophryoscolecidae)}

The buccal infraciliature was composed of three polybrachykineties, a kinety loop, and paralabial kineties. The adoral and dorso-adoral polybrachykineties surrounded the vestibular opening, a kinety loop connected them, and the vestibular polybrachykinety extended inside the vestibulum. The wide, adoral polybrachykinety encircled most of the circumference of the vestibular opening, which arched ventrally from its right to left side, and inclined ventrally. The large dorso-adoral polybrachykinety was located at the dorsal side of the vestibular opening. The adoral polybrachykinety and the dorso-adoral polybrachykinety were connected by a kinety loop. This kinety loop was a very narrow polybrachykinety by kineties in which each kinety row decreased in length. The vestibular polybrachykinety extended along the dorsal wall of the vestibulum from the dorsal edge of the vestibular opening to the level of the anterior part of the macronucleus. The vestibular polybrachykinety had a gentle S-shaped curve. Paralabial kineties were observed along the ventral side of the adoral polybrachykinety. The number of these kineties was four. Kinetids in the paralabial kineties were slightly larger than the kinetids in the other polybrachykineties. The dorsal polybrachykinety extended laterally along the dorsal side of the body (Figs 1,2). 
Table 1. Frequency of appearance and percentage composition of ciliates in the rumen contents of 15 cattle living in İstanbul, Turkey.

\begin{tabular}{|c|c|c|c|}
\hline \multirow{2}{*}{ Genus/species/morphotype } & \multirow{2}{*}{ Frequency appearance (\%) } & \multicolumn{2}{|c|}{ Percentage composition $(\%)$} \\
\hline & & Mean \pm SD & Range \\
\hline Charonina Strand, 1928 & 40 & $1.7 \pm 3.1$ & $0-11.8$ \\
\hline C. ventriculi (Jameson, 1925) & 40 & $1.7 \pm 3.1$ & $0-11.8$ \\
\hline Dasytricha Schuberg, 1888 & 93.3 & $6.5 \pm 6.5$ & $0-24.4$ \\
\hline D. ruminantium Schuberg, 1888 & 93.3 & $6.5 \pm 6.5$ & $0-24.4$ \\
\hline Diplodinium Schuberg, 1888 & 46.7 & $2.6 \pm 4.6$ & $0-14.7$ \\
\hline D. anisacanthum Da Cunha, 1914 & 6.7 & $0.5 \pm 2.0$ & $0-7.9$ \\
\hline m. anisacanthum Da Cunha, 1914 & 6.7 & $0.5 \pm 2.0$ & $0-7.9$ \\
\hline D. dentatum (Stein, 1858) & 40 & $0.9 \pm 1.4$ & $0-4.1$ \\
\hline D. dogieli Kofoid and MacLennan, 1932 & 6.7 & $0.8 \pm 3.2$ & $0-12.2$ \\
\hline D. rangiferi Dogiel, 1925 & 6.7 & $0.3 \pm 1.3$ & $0-5.0$ \\
\hline Enoploplastron Kofoid and MacLennan, 1932 & 6.7 & $0.1 \pm 0.4$ & $0-1.6$ \\
\hline E. triloricatum (Dogiel, 1925) & 6.7 & $0.1 \pm 0.4$ & $0-1.6$ \\
\hline Entodinium Stein, 1859 & 100 & $61.8 \pm 16.6$ & $36.5-83.1$ \\
\hline E. bifidum Dogiel, 1927 & 20 & $1.4 \pm 3.9$ & $0-15.1$ \\
\hline m. bifidum Dogiel, 1927 & 13.3 & $0.8 \pm 2.4$ & $0-9.0$ \\
\hline m. monospinosum Ito et al., 1994 & 20 & $0.9 \pm 2.1$ & $0-6.1$ \\
\hline E. bimastus Dogiel, 1927 & 26.7 & $0.8 \pm 1.5$ & $0-4.5$ \\
\hline E. bursa Stein, 1858 & 33.3 & $1.2 \pm 1.9$ & $0-5.4$ \\
\hline E. dilobum (Dogiel, 1927) & 40 & $1.2 \pm 1.6$ & $0-4.1$ \\
\hline E. dubardi Buisson, 1923 & 33.3 & $4.7 \pm 7.4$ & $0-20.0$ \\
\hline E. ellipsoideum (Kofoid and MacLennan, 1930) & 53.3 & $4.2 \pm 5.5$ & $0-16.1$ \\
\hline E. exiguum Dogiel, 1925 & 20 & $1.1 \pm 2.2$ & $0-6.1$ \\
\hline E. longinucleatum Dogiel, 1925 & 80 & $9.5 \pm 6.5$ & $0-22.0$ \\
\hline E. minimum Schuberg, 1888 & 60 & $4.7 \pm 4.9$ & $0-15.8$ \\
\hline E. nanellum Dogiel, 1923 & 46.7 & $5.9 \pm 7.5$ & $0-19.8$ \\
\hline E. rostratum Fiorentini, 1889 & 40 & $4.9 \pm 8.0$ & $0-25.8$ \\
\hline E. simulans Lubinsky, 1957 & 93.3 & $16.1 \pm 9.2$ & $0-35.6$ \\
\hline m. dubardi Lubinsky, 1957 & 26.7 & $4.7 \pm 7.4$ & $0-20.0$ \\
\hline m. lobosospinosum Lubinsky, 1957 & 26.7 & $1.5 \pm 2.8$ & $0-8.9$ \\
\hline m. caudatum Lubinsky, 1957 & 86.7 & $9.9 \pm 5.6$ & $0-18.6$ \\
\hline E. triacum Dogiel, 1927 & 53.3 & $4.8 \pm 3.0$ & $0-22.3$ \\
\hline m. triacum Dogiel, 1927 & 53.3 & $4.8 \pm 3.0$ & $0-22.3$ \\
\hline Eodinium Kofoid and MacLennan, 1932 & 20 & $0.7 \pm 1.6$ & $0-5.9$ \\
\hline E. posterovesiculatum (Dogiel, 1927) & 20 & $0.7 \pm 1.6$ & $0-5.9$ \\
\hline m. monolobosum (Hsiung, 1932) & 13.3 & $0.5 \pm 1.5$ & $0-5.9$ \\
\hline m. bilobosum (Dogiel, 1927) & 6.7 & $0.2 \pm 0.7$ & $0-2.6$ \\
\hline Epidinium Crawley, 1923 & 53.3 & $8.6 \pm 10.4$ & $0-28.2$ \\
\hline E. ecaudatum (Fiorentini, 1889) & 53.3 & $8.6 \pm 10.4$ & $0-28.2$ \\
\hline m. ecaudatum (Fiorentini, 1889) & 20 & $1.1 \pm 2.6$ & $0-8.9$ \\
\hline m. caudatum (Fiorentini, 1889) & 53.3 & $7.1 \pm 8.9$ & $0-26.3$ \\
\hline m. quadricaudatum Sharp, 1914 & 6.7 & $0.4 \pm 1.4$ & $0-5.4$ \\
\hline Eudiplodinium Dogiel, 1927 & 26.7 & $2.7 \pm 4.8$ & $0-13.8$ \\
\hline
\end{tabular}




\begin{tabular}{|c|c|c|c|}
\hline \multirow{2}{*}{ Genus/species/morphotype } & \multirow{2}{*}{ Frequency appearance $(\%)$} & \multicolumn{2}{|c|}{ Percentage composition (\%) } \\
\hline & & Mean \pm SD & Range \\
\hline E. dilobum (Dogiel, 1927) & 13.3 & $0.6 \pm 1.8$ & $0-6.5$ \\
\hline E. maggii (Fiorentini, 1889) & 13.3 & $0.7 \pm 2.0$ & $0-7.4$ \\
\hline E. rostratum (Fiorentini, 1889) & 20 & $1.4 \pm 3.0$ & $0-9.5$ \\
\hline Isotricha Stein, 1859 & 93.3 & $5.1 \pm 3.6$ & $0-15.5$ \\
\hline I. intestinalis Stein, 1858 & 33.3 & $0.4 \pm 0.7$ & $0-1.8$ \\
\hline I. prostoma Stein, 1858 & 93.3 & $4.7 \pm 3.8$ & $0-15.5$ \\
\hline Metadinium Awerinzew and Mutafowa, 1914 & 66.7 & $3.4 \pm 3.9$ & $0-13.6$ \\
\hline M. affine (Dogiel and Fedorowa, 1925) & 60 & $2.5 \pm 2.7$ & $0-7.7$ \\
\hline M. medium Awerinzew and Mutafowa, 1914 & 6.7 & $<0.1 \pm 0.1$ & $0-0.4$ \\
\hline Ophryoscolex Stein, 1859 & 46.7 & $1.1 \pm 1.4$ & $0-3.8$ \\
\hline O. purkynjei Stein, 1858 & 46.7 & $1.1 \pm 1.4$ & $0-3.8$ \\
\hline m. purkynjei Stein, 1858 & 46.7 & $1.1 \pm 1.4$ & $0-3.8$ \\
\hline Ostracodinium Dogiel, 1927 & 53.3 & $1.2 \pm 1.4$ & $0-4.8$ \\
\hline O. dogieli (Dogiel, 1927) & 26.7 & $0.5 \pm 0.8$ & $0-2.4$ \\
\hline O. gracile (Dogiel, 1925) & 13.3 & $0.3 \pm 0.8$ & $0-2.8$ \\
\hline O. mammosum (Railliet, 1890) & 6.7 & $0.3 \pm 1.2$ & $0-4.8$ \\
\hline O. munham Ito et al., 1994 & 6.7 & $0.1 \pm 0.6$ & $0-2.2$ \\
\hline Polyplastron Dogiel, 1927 & 60 & $2.3 \pm 3.9$ & $0-15.7$ \\
\hline P. multivesiculatum (Dogiel and Fedorowa, 1923) & 60 & $2.3 \pm 3.9$ & $0-15.7$ \\
\hline
\end{tabular}

Total species, morphotypes, and genera number: 33, 13, and 13.

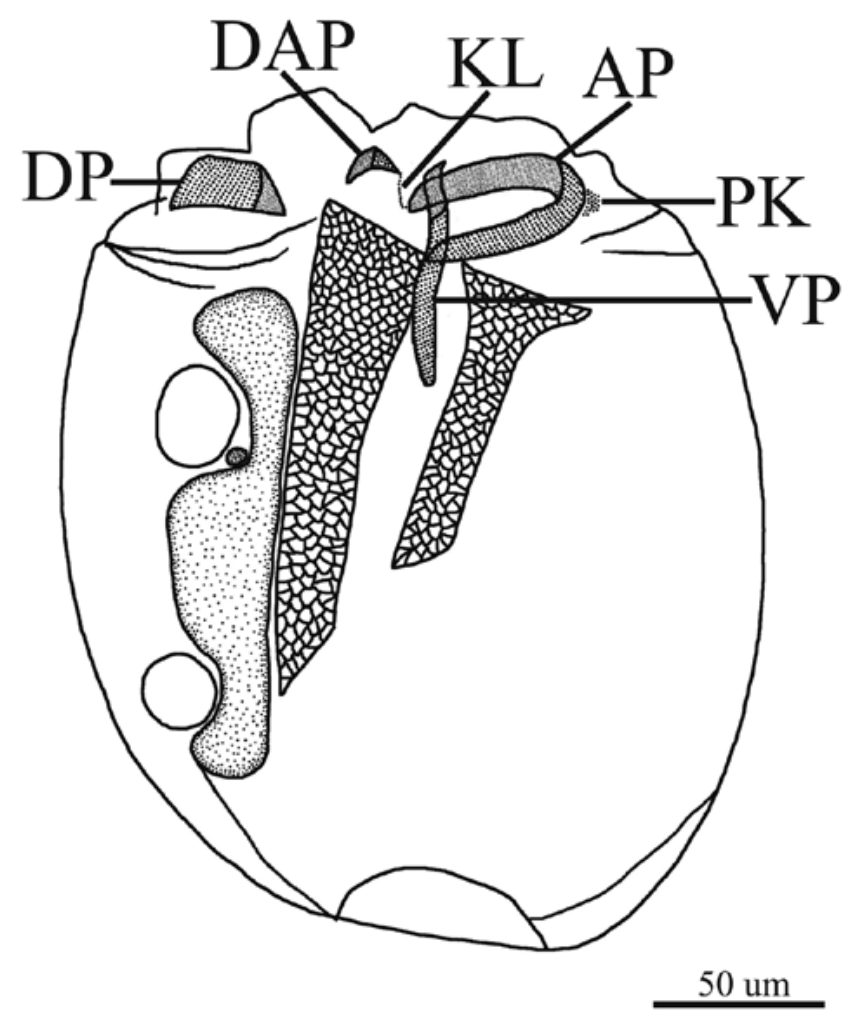

Fig. 1. Schematic figure of infraciliature of Metadinium medium from the right side, after pyridinated silver carbonate impregnation. AP - adoral polybrachykinety, DAP - dorso-adoral polybrachykinety, DP - dorsal polybrachykinety, KL - kinety loop, PK - paralabial kineties, VP - vestibular polybrachykinety.

\section{D}

Fig. 2. Photomicrographs of $M$. medium, after pyridinated silver carbonate impregnation. $\mathbf{a}, \mathbf{b}-$ from the right side, $\mathbf{c}, \mathbf{d}-$ from the left side. AP - adoral polybrachykinety, DAP - dorso-adoral polybrachykinety, DP - dorsal polybrachykinety, KL - kinety loop, $\mathrm{PK}$ - paralabial kineties, VP - vestibular polybrachykinety. 
Rumen Ciliates of Domestic Cattle 175

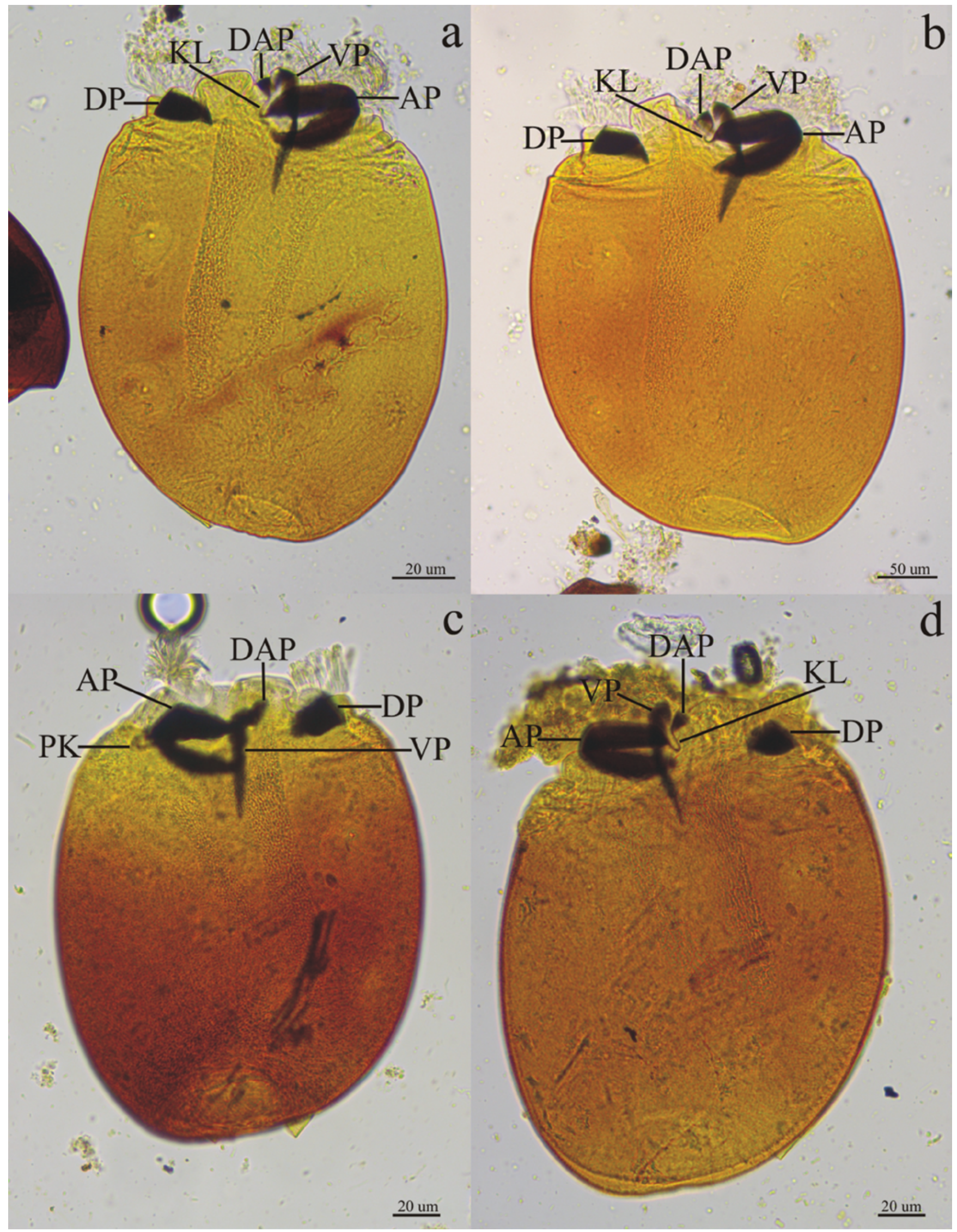


Division was by transverse binary fission, perpendicular to the longitudinal axis. The buccal and dorsal polybrachykineties of the opisthe formed without any relationship to the polybrachykineties of the proter. Division began when the three ciliary bands appeared. Three ciliary bands; that is, the dorsal, ventral, and left primordia, were composed of numerous short, oblique kineties during division. The right end of the ventral primordium extended dorsally as a band that was narrow in the middle and wide at its extremity. The widened part of the ventral primordium extended and grew into a right primordium. The ventral and right primordia were connected by a narrow polybrachykinety. The primordium of the paralabial kineties arose along the ventral side of the ventral primordium. The left primordium was at the same level of the ventral and dorsal primordium and under the right primordium. The left primordium tilted obliquely relative to the longitudinal axis of the body. The right primordium and the dorsal extremity of the left primordium approached each other. The ventral, right, left, and dorsal primordia develop into adoral, dorsoadoral, vestibular, and dorsal polybrachykineties of the opisthe, respectively, after binary fission. The kinety loop of the opisthe originated from the kineties between the ventral and right primordia (Fig. 3).

\section{DISCUSSION}

In this study, 35 species and 13 morphotypes belonging to 13 genera were detected in the ruminal contents of 15 cattle (B. taurus taurus L.) living in the European part of İstanbul, Turkey. E. posterovesiculatum $\mathrm{m}$. bilobosum and $D$. dogieli are new host records for cattle from Turkey, but no novel species were observed.

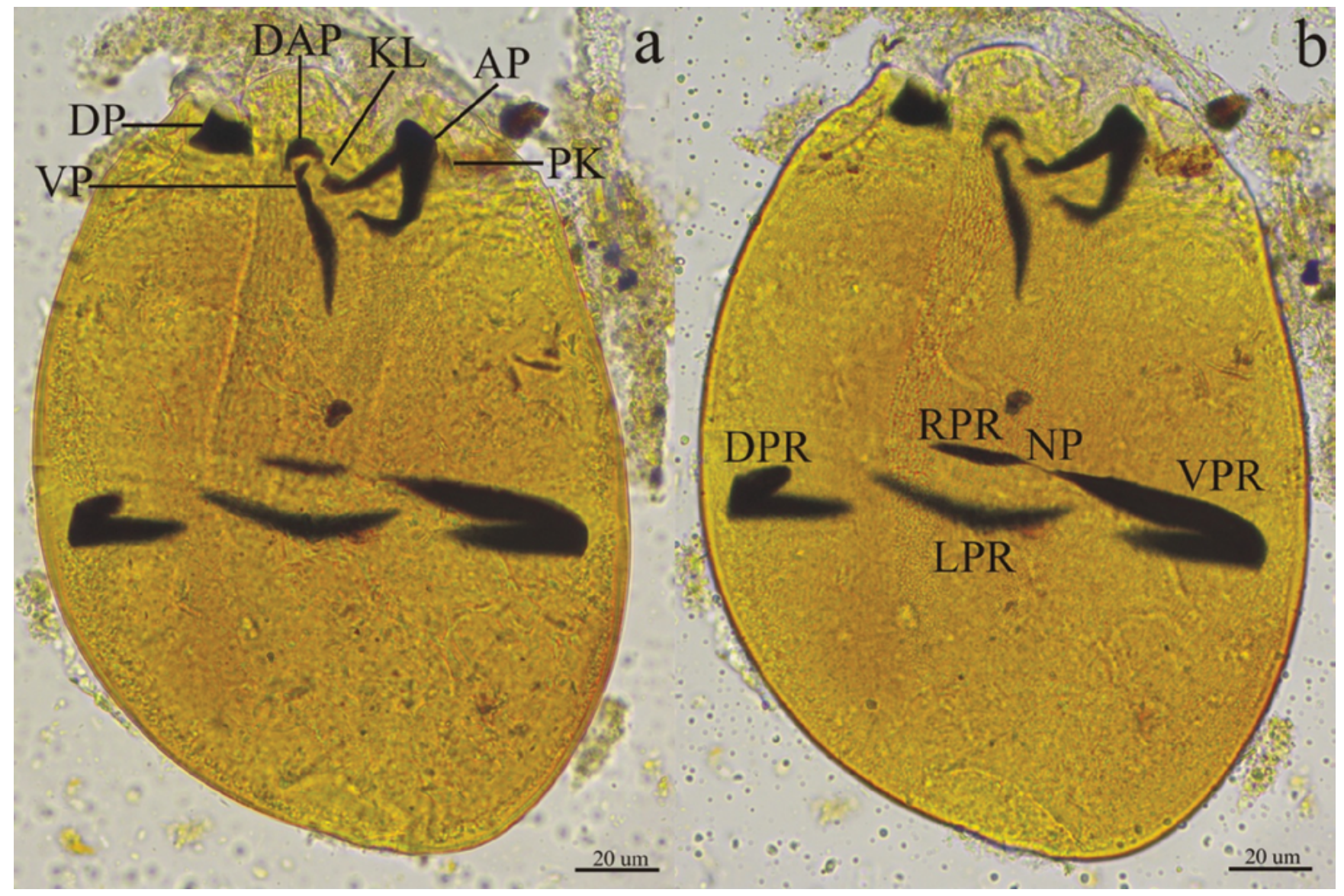

Fig. 3. Photomicrographs of M. medium in binary fission from the right side, after pyridinated silver carbonate impregnation. AP - adoral polybrachykinety, DAP - dorso-adoral polybrachykinety, DP - dorsal polybrachykinety, DPR - dorsal primordium, KL - kinety loop, $\mathrm{LP}$ - left primordium, NP - narrow polybrachykinety between ventral and right primordia, $\mathrm{PK}$ - paralabial kineties, RPR - right primordium, $\mathrm{VP}$ - vestibular polybrachykinety, VPR - ventral primordium. 


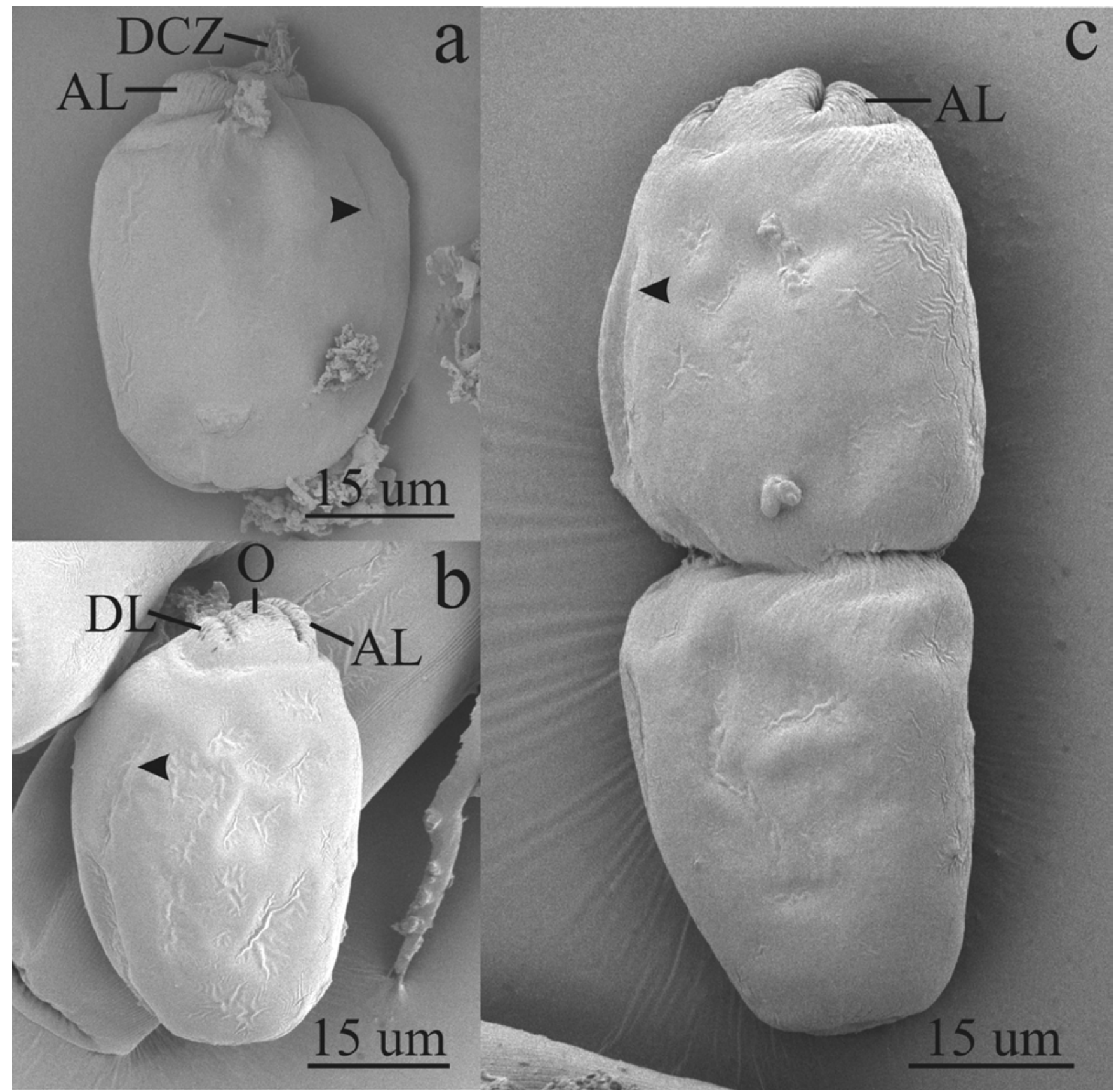

Fig. 4. SEM images of Diplodinium dogieli. $\mathbf{a}$ - from the left side, $\mathbf{b}-$ from the right side, $\mathbf{c}-$ from the right side in binary fission. AL - adoral lip, DCZ - dorsal ciliary zone, DL - dorsal lip, O - operculum. Narrow longitudinal thickening of the pellicle (arrowheads).

D. dogieli is found principally in wild ruminants, such as reindeer, deer, and musk-ox (Dehority 1985; Dehority et al. 1999; Dogiel 1925; Imai et al. 2004; Lubinsky 1958), but three records of it exist from domesticated animals, such as alpaca, cattle, and sheep (Del, Valle et al. 2008; Hukui 1940; Marinho 1983). This is the second report from cattle after the record from Japanese cattle by Hukui (1940). This ciliated species is ellipsoidal with a truncated anterior and rounded posterior end. A narrow longitudinal thickening of the pellicle extended along the right dorsal surface from the anterior end to the cytoproct (Figs 4, 5).

Mean ciliate density in the ruminal contents of domestic cattle living in the European part of İstanbul 


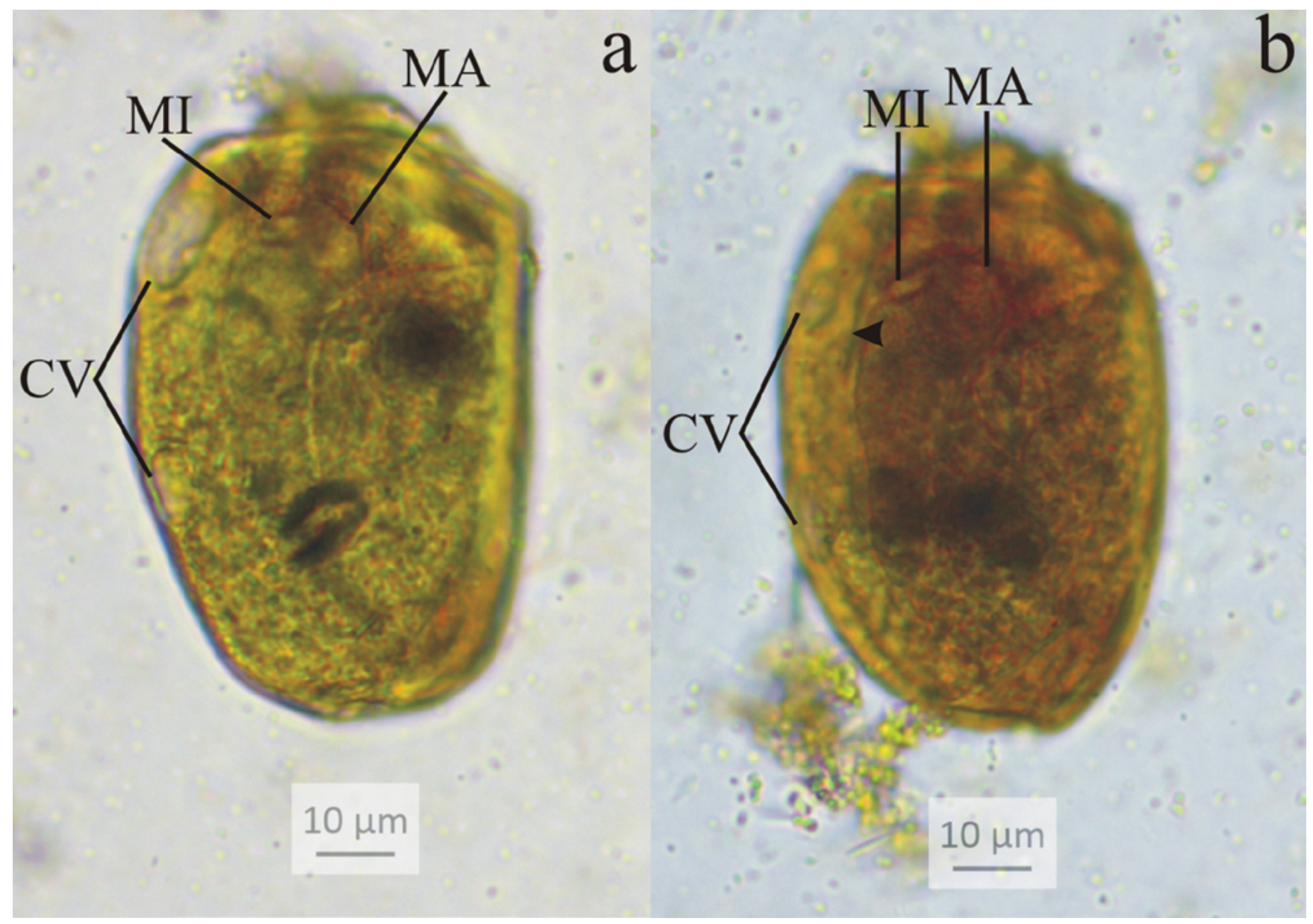

Fig. 5. Photomicrographs of D. dogieli. a, b - in MFS and Lugol's iodine from the right side. CV - contractile vacuole, MA - macronucleus, MI - micronucleus. Narrow longitudinal thickening of the pellicle (arrowhead).

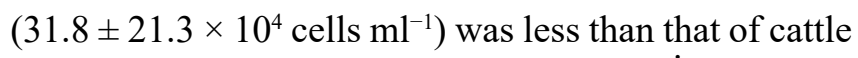
in Kastamonu (Gürelli 2016b) and cattle in İzmir (Göçmen et al. 2003), which are both in the Anatolian part of Turkey. This variation may be due to their different geographical locations, their respective diets, the number of hosts examined, or a combination of these factors.

Of the ciliate species, Dasytricha ruminantium, Entodinium simulans, and Isotricha prostoma were most abundant, each with a prevalence of $93.3 \%$, whereas Diplodinium anisacanthum, D. dogieli, D. rangiferi, Enoploplastron triloricatum, Metadinium medium, and Ostracodinium munham were detected only in one animal (6.7\% prevalence). Dasytricha, Entodinium spp., and Isotricha spp. are very common ciliates in the rumen, possibly due to the very widespread distribution of these species or the animal's diets. Entodinium spp. rapidly grow, and their relative frequency increases when the host is fed a concentrate-rich ration (Hungate 1966).
In this study, the infraciliature of M. medium (Entodiniomorphida, Ophryoscolecidae) was examined and detected for the first time. M. medium has a different buccal infraciliature pattern from that of other ophryoscolecid species. However, the M. medium-type buccal infraciliature pattern looks like that of the Ostracodinium gracile-type and $O$. mammosum-type buccal infraciliature patterns. Ito et al. (1997), Ito and Imai (1998), and Ito et al. (2001) studied buccal infraciliature of Ostracodinium spp. and three buccal infraciliature patterns, such as the O. gracile-type, O. mammosum-type, and $O$. damaliscus-type were detected. The O. mammosum-type buccal infraciliature pattern has a small, drop-shaped dorso-adoral polybrachykinety, a gentle curved vestibular polybrachykinety, and a kinety loop between the adoral and dorso-adoral polybrachykineties (Ito et al. 2001). However, the shape of the dorso-adoral and vestibular polybrachykineties 
of the $M$. medium-type buccal infraciliature differs from that of the $O$. mammosum-type buccal infraciliature. The $O$. gracile-type buccal infraciliature pattern has a large dorso-adoral polybrachykinety, S-shape curved vestibular polybrachykinety, and adoral polybrachykinety like the $M$. medium-type, but no kinety loop is between the adoral and dorso-adoral polybrachykinety (Ito and Imai 1998). The shape and position of the dorsal polybrachykinety are the same in the three buccal infraciliature patterns. The dorso-adoral and vestibular polybrachykineties are slender in the $O$. damaliscustype buccal infraciliature, and the kinety loop is well developed between the adoral and dorso-adoral polybrachykineties (Ito et al. 1997).

M. medium has a tubular vestibulum like Ostracodinium, Epidinium, Ophryoscolex, Enoploplastron, and Eodinium, whereas the vestibulum in Entodinium, Diplodinium, Eudiplodium, and Polyplastron is funnel-shaped (Ito and Imai 2003, 2006, 2005; Ito et al. 2002; Mishima et al. 2009). According to Ito and Imai (2006), when the funnel-shaped vestibulum changed to become tubular, the dorso-adoral polybrachykinety and the kinety loop appeared, and the vestibular polybrachykinety became slender. The buccal infraciliature patterns reveal the evolutionary relationship in the family Ophryoscolecidae. Until now, there were 12 buccal infraciliature patterns described for representatives of the family Ophryoscolecidae, including the Entodinium-type, Diplodinium-type, Diplodinium polygonale-type, D. leche-type, D. nanum-type, Eodinium posterovesiculatum-type, O. gracile-type, O. mammosum-type, O. damaliscus-type, Enoploplastron stokyitype, Epidinium-type, and Ophryoscolex-type (Ito and Imai 2003, 2006, 2005; Ito et al. 1997, 1998, 2001; Mishima et al. 2009; Noirot-Timothée 1960). The Entodinium-type buccal infraciliature has only adoral and vestibular polybrachykineties with the same width (Ito and Imai 2006; Mishima et al. 2009). Ruminal ciliates with the Entodinium-type buccal infraciliature could be ancestral in the family Ophryoscolecidae (Ito and Imai 2005). The Diplodinium-type has adoral, vestibular, and dorsal polybrachykineties, and the adoral and vestibular polybrachykineties have the same width (Ito and Imai 2003). The D. polygonale-type, D. lechetype, and D. nanum-type have adoral, vestibular, and dorsal polybrachykineties. However, the direction of the vestibular polybrachykineties of these types differs from that of the Diplodinium-type, so these types of buccal infraciliatures could be intermediate between the Entodinium-type and Diplodinium-type buccal in- fraciliatures (Ito and Imai 2003, 2005). The Ostracodinium-types and $M$. medium-type buccal infraciliatures have an additional polybrachykinety, called the dorsoadoral polybrachykinety. However, no kinety loop occurs between the adoral and dorso-adoral polybrachykineties in $O$. gracile-type buccal infraciliature but the kinety loop exists in the $O$. mammosum-type and O. damaliscus-type buccal infraciliatures (Ito and Imai 1997, 1998, 2001). Ito and Imai (2006) proposed the evolution of the $O$. mammosum-type buccal infraciliature from the $O$. gracile-type buccal infraciliature. According to the present results, $M$. medium-type buccal infraciliature could have evolved from the $O$. graciletype and has an intermediate position between the $O$. gracile-type and $O$. mammosum-type buccal infraciliature. Taken together, if the buccal infraciliature patterns compare in Ophryoscolecidae, the evolutionary rank of the buccal infraciliature is Entodinium-type, D. polygonale-type, D. leche-type, D. nanum-type, Diplodiniumtype, $O$. gracile-type, $M$. medium-type, $O$. mammosumtype, O. damaliscus-type, Enoploplastron stokyi-type, Epidinium-type, and Ophryoscolex-type, respectively. However, the Eodinium-type buccal infraciliature has not been placed in this rank because this species displays an exceptional vestibular polybrachykinety in the family Ophryoscolecidae (Ito and Imai 2003).

There are thirteen buccal infraciliature patterns with together M. medium-type in Ophryoscolecidae and phylogenetic relationships between six of them, Entodinium-type, Diplodinium-type, O. gracile-type, O. mammosum-type, Epidinium-type, and Ophryoscolex-type were also confirmed with the molecular study (Rossi et al. 2015).

The buccal infraciliature is an important character for understanding the evolutionary relationships among the rumen ciliates in family Ophryoscolecidae, and more studies on rumen ciliates are necessary to reveal unknown buccal infraciliature patterns.

Acknowledgements. We would like to express our appreciation to the Research and Application Center of Kastamonu University for SEM images.

\section{REFERENCES}

Dehority B. A. (1978) Specificity of rumen ciliate protozoa in cattle and sheep. J. Protozool. 25: 509-513.

Dehority B. A. (1984) Evaluation of subsampling and fixation procedures used for counting rumen protozoa. Appl. Environ. Microbiol. 48: 182-185.

Dehority B. A. (1985) Rumen ciliates of Musk-oxen (Ovibos moschatus Z.) from the Canadian arctic. J. Protozool. 32: 246-250. 
Dehority B. A. (1986) Protozoa of the digestive tract of herbivorous mammals. Insect Sci. Appl. 7: 279-296.

Dehority B. A. (1993) Laboratory Manual for Classification and Morphology of Rumen Ciliate Protozoa. CRC Press, Florida.

Dehortiy B. A., Demarais S., Osborn D. A. (1999) Rumen ciliates of white-tailed deer (Odocoileus virginianus), axis deer (Axis axis), sika deer (Cervus nippon) and fallow deer (Dama dama) from Texas. J. Eukaryot. Microbiol. 46: 125-131.

Del Valle I., De la Fuente G., Fondevila M. (2008) Ciliate protozoa of the forestomach of llamas (Lama glama) and alpacas (Vicugna pacos) from the Bolivian Altiplano. Zootaxa 1703: 62-68.

Dogiel V. A. (1925) Neue parasistische infusorien aus dem magen des renntieres (Rangifer tarandus). Arch. Rus. Protistol. 4: 43-65.

Dogiel V. A. (1927) Monographie der Familie Ophryoscolecidae. Arch. Protistenkd. 59: 1-288.

Fernández-Galiano T., Serrano S., Fernández-Galiano D. (1985) General morphology and stomatogenesis of two species of the genus Entodinium (Ciliophora, Entodiniomorphida). Acta Protozool. 24: 181-186.

Göçmen B., Dehority B. A., Rastgeldi S. (2003) Ciliated protozoa in the rumen of Turkish domestic cattle (Bos taurus L.). J. Eukaryot. Microbiol. 50: 104-108.

Gürelli G. (2014) Rumen ciliate fauna (Ciliophora, Protista) of Turkish domestic goats living in İzmir, Turkey. Turk. J. Zool. 38: $136-143$.

Gürelli G. (2016a) Rumen ciliate biota of water buffalo (Bubalus bubalis Linnaeus, 1758) in Kastamonu, Turkey. Turk. J. Zool. 40: 586-594.

Gürelli G. (2016b) Rumen ciliates of domestic cattle (Bos taurus taurus) in Kastamonu, Turkey with the description of a new species. Eur. J. Protistol. 56: 51-59.

Hukui T. (1940) Untersuchungen tiber die drei neuen und vierzehn bekannten Ciliaten von Bos taurus var domesticus Gmelin in West Japan. J. Sci. Hiroshima Univ. 7: 169-181.

Hungate R. E. (1966) The Rumen and Its Microbes. Academic Press, New York.

Imai S. (1988) Ciliate protozoa in the rumen of Kenyan zebu cattle, Bos taurus indicus, with the description of four new species. $J$. Protozool. 35: 130-136.

Imai S., Tsutsumi Y., Yumura S., Mulenga A. (1992) Ciliate protozoa in the rumen of Kafue lechwe, Kobus leche kafuensis, in Zambia, with the description of four new species. J. Protozool. 39: $564-572$.

Imai S., Oku Y., Morita T., Ike K., Rong G. (2004) Rumen ciliate protozoal fauna of reindeer in inner Mongolia, China. J. Vet. Med. Sci. 66: 209-212.

Ito A., Imai S. (1990) Ciliated protozoa in the rumen of HolsteinFriesian cattle (Bos taurus taurus) in Hokkaido, Japan, with the description of two new species. Zool. Sci. 7: 449-458.

Ito A., Imai S. (1998) Infraciliary bands in the rumen ophryoscolecid ciliate Ostracodinium gracile (Dogiel, 1925), observed by light microscopy. J. Eukaryot. Microbiol. 45: 628-636.
Ito A., Imai S. (2003) Light microscopical observation of infraciliary bands of Eodinium posterovesiculatum in comparison with Entodinium bursa and Diplodinium dentatum. J. Eukaryot. Microbiol. 50: $34-42$.

Ito A., Imai S. (2005) Infraciliature and morphogenesis in three rumen Diplodinium ciliates, Diplodinium polygonale, Diplodinium leche, and Diplodinium nanum, observed by light microscopy. J. Eukaryot. Microbiol. 52: 44-51.

Ito A., Imai S. (2006) Infraciliary band pattern of rumen ophryoscolecid ciliates. Endocytobio. Cell Res. 17: 103-110.

Ito A., Arai N., Tsutsumi Y., Imai S. (1997) Ciliate protozoa in the rumen of sassaby antelope, Damaliscus lunatus lunatus, including the description of a new species and form. J. Eukaryot. Microbiol. 44: 586-591.

Ito A., Miyazaki Y., Imai S. (2001) Light microscopic observations of infraciliature and morphogenesis in six species of rumen $O s$ tracodinium ciliates. J. Eukaryot. Microbiol. 48: 440-448.

Kofoid C. A., MacLennan R. F. (1932) Ciliates from Bos indicus Linn. II. A revision of Diplodinium Schuberg. Univ. California Pub. Zool. 37: 53-152.

Lubinsky G. (1958) Ophryoscolecidae (Ciliata: Entodiniomorphida) of reindeer (Rangifer tarandus L.) from the Canadian Arctic. II. Diplodiniinae. Canad. J. Zool. 36: 937-959.

Lynn D. H. (2008) The Ciliated Protozoa: Characterization, Classification, and Guide to the Literature. Springer, Dordrecht.

Marinho A. A. (1983) Protozoários ciliados no rúmen de ovinos em pastoreio (Ciliate protozoa in the rumen of grazing sheep). Rev. Port. Ciene. Veter. 78: 157-165.

Mishima T., Katamoto H., Horii Y., Kakengi V. A. M., Ito A. (2009) Rumen ciliates from Tanzanian short horn zebu cattle, Bos taurus indicus, and the infraciliature of Entodinium palmare n. sp. and Enoploplastron stokyi (Buisson, 1924). Eur. J. Protistol. 45: 77-86.

Moon-van der Staay S. Y., van der Staay G. W. M., Michalowski T., Jouany J.-P. Pristas P., Javorský P., Kišidayová S., Varadyova Z, McEwan N. R., Newbold C. J., van Alen T., de Graaf R., Schmid M., Huynen M. A., Hackstein J. H. P. (2014) The symbiotic intestinal ciliates and the evolution of their hosts. Eur. J. Protistol. 50: 166-173.

Noirot-Timothée C. (1960) Étude d'une famille de ciliés: les Ophryoscolecidae. Structures et ultrastructures. Ann. Sci. Nat. Zool. 2: $527-718$.

Ogimoto K., Imai S. (1981) Atlas of Rumen Microbiology. Japan Scientific Societies Press, Tokyo.

Rossi M. F., Dias R. J. P., Senra M. V. X., Martinele I., Soares C. A. G., D’Agosto M. (2015) Molecular phylogeny of the family Ophryoscolecidae (Ciliophora, Litostomatea) inferred from 18S rDNA Sequences. J. Eukaryot. Microbiol. 62: 584-590.

Williams A. G., Coleman G. S. (1992) The Rumen Protozoa. Springer, New York.

Received on $6^{\text {th }}$ July, 2017; revised on $21^{\text {st }}$ September, 2017; accepted on $26^{\text {th }}$ September, 2017 